\title{
Hypertension: A global health crisis
}

\section{Pius AL Berek*, Dewi Irawati and Akhir Yani S Hamid}

Faculty of Nursing, University of Indonesia, Gedung Utama Pasca Sarjana Gedung Pendidikan \& Laboratorium FIK UI, JI. Prof. Dr. Bahder Djohan, Kampus UI Depok, West Java, Indonesia

\section{Abstract}

Objective: This study discusses strategies to overcome hypertension patient compliance to manage self-care. The purpose of the study is to provide a summary of the importance of attention to managing hypertension.

Method: A review of literature relevant to hypertension, policies, and management, both pharmacological and non-pharmacological, through cross-programs or sectors.

Result: This study found that the ministry of health had compiled various policies to reduce the prevalence of hypertension, including technical guidelines for its implementation, but the strategy has not yet fully reached the minimum service standard, which is because it has not fully involved the relevant cross sectors.

Conclusion: Improve the coordination system by "Joint Decree" between the Ministry of Health and the Ministry of Villages, PDT and Transmigration, the Ministry of Social Affairs, Indonesian National Army, police, and NGOs to carry out activities simultaneously to the community.

\author{
More Information \\ *Address for Correspondence: Pius AL Berek, \\ Faculty of Nursing, University of Indonesia, \\ Gedung Utama Pasca Sarjana Gedung \\ Pendidikan \& Laboratorium FIK UI, JI. Prof. Dr. \\ Bahder Djohan, Kampus UI Depok, West Java, \\ Indonesia, Tel: +62-81317493441; \\ Email: francisdomin2018@gmail.com \\ Submitted: June 19, 2021 \\ Approved: July 12, 2021 \\ Published: July 14, 2021
}

How to cite this article: AL Berek P, Irawati D, Hamid AYS. Hypertension: A global health crisis. Ann Clin Hypertens. 2021; 5: 008-011.

DOI: 10.29328/journal.ach.1001027 ORCID: orcid.org/0000-0001-8082-8198

Copyright: @ 2021 AL Berek P, et al. This is an open access article distributed under the Creative Commons Attribution License, which permits unrestricted use, distribution, and reproduction in any medium, provided the original work is properly cited.

Keywords: Policy Brief; Hypertension; Health Crisis

\section{(A) Check for updates}

(ึ) OPEN ACCESS

\section{Background}

Globally, 17 million deaths per year are caused by cardiovascular disease, nearly one-third of total deaths. Complications from hypertension number are 9.4 million deaths worldwide each year. Hypertension is believed to be responsible for at least $45 \%$ of deaths due to heart disease and $51 \%$ of deaths due to stroke [1].

World Health Organization (WHO) explains that developing countries have hypertension by $40 \%$ while developed countries have $35 \%$, Africa places the top position of hypertension sufferers, which is equal to $40 \%$ [1]. In Indonesia, it is $32 \%$ of the total population [2]. This disease kills 1.5 million people every year. This indicates one in three people suffer from hypertension. Since 2008, around $40 \%$ of adults aged 25 years and over around the world, have been diagnosed with hypertension [1]. As a result of a weak health system, so many people with hypertension are undiagnosed, untreated, and not well controlled. This is particularly common in low and middle-income countries [3]. The prevalence of hypertension by gender in men is $31.34 \%$ compared to women. Different based on age, but generally found hypertension in women is greater than in men [4].

Deaths due to non-contagious diseases tend to increase including cardiovascular. Populations around the world are rapidly declining and the prevalence of hypertension gets increased over a while. The increasing life expectancy of Indonesia is getting higher at 72.2 years [5] is also a predictor of hypertension. If appropriate action is not taken, deaths of cardiovascular disease are predicted to increase further [1].

Nearly $80 \%$ of deaths of cardiovascular disease take place in low and middle-income countries. They are the countries that are least able to bear the social and economic consequences of ill health. The current standard mortality rate in low-income countries is higher than in developed countries [1].

The impact of hypertension can be early death, disability, personal and family disorders, loss of income, and health care expenses, which are very detrimental to the family, community, and national finance. Many people in developing countries do not look for treatment for hypertension because it is unaffordable. They often spend most of their earnings on hospitalization and care after hypertension complications, including heart attacks, strokes, and kidney illness. The patient will acquire large costs for health care, especially related to hypertension and its complications. In addition, it would be devastating when a family loses income due to death or disability. 
Current health expense on cardiovascular disease reaches $20 \%$ of total health expenditure. During 2011-2025, the cumulative output lost due to non-contagious diseases is predicted to reach the US $\$ 7.28$ trillion. Annual losses around the US $\$ 500$ billion due to non-contagious diseases account for around $4 \%$ of gross-domestic-product for low and middle-income countries. Cardiovascular disease including hypertension accounts for almost half of these costs [1].

The increased incidence of non-contagious diseases will lead to greater dependence and increased care costs for patients and their families. The Political Declaration of the General Assembly High-Level Meeting on Prevention and Control of Non-Contagious Diseases, adopted by the General Assembly of the United Nations in September 2011, has recognized that the burden of non-contagious diseases is growing rapidly and harms health, socio-economic development and alleviation poverty. Consequently, the government needs to carry out a series of concrete actions. If no action is taken to overcome hypertension and other non-contagious diseases, economic losses are estimated to exceed public health expenditure.

\section{Method}

A review of literature relevant to hypertension, policies, and management, both pharmacological and nonpharmacological, through cross-programs or sectors.

\section{Result}

\section{Framework and urgency in management of hypertension}

Many studies have shown that hypertension sufferers are not compliant with their treatment, both medication and self-care including consumption of unhealthy foods, habits of inactivity, smoking and drinking alcohol, etc [6]. Many studies have been conducted to reduce the prevalence of hypertension, including slow deep breathing and sodium diet regulation [7]. However, it has not been able to suppress the incidence of hypertension. WHO (2014) states that hypertension will increase with the increase in the expected age of Indonesian people, which is 72.2 years [5]. The increasing life expectancy of the people of Indonesia, will also have an impact on the incidence of hypertension, supported again by the daily lifestyle, especially the instant lifestyle and lack of activity. Fast food patterns, alcohol, and cigarette consumption, and eating foods high in sodium will increase hypertension in the future.

The Ministry of the Republic of Indonesia has strived to reduce the prevalence of hypertension by $25 \%$, this is still far from expectations. It is increasing $[8,9]$. The promotive and preventive efforts that have been launched. The program of CERDIK-PATUH and the Healthy Indonesia Program with a Family Approach (PIS-PK) are very useful to reduce the incidence of hypertension, but the incidence of hypertension is still difficult to stem. The increasing cases of hypertension did not rule out the possibility of complications in the form of heart and blood vessel problems in the form of heart attack, heart failure, and also kidney failure, and other health problems. More and more strategies to reduce the prevalence of hypertension, but the cases are increasing. This is needed to be analyzed, what causes it? The extent to which patients adhere to the program that has been planned. Therefore, according to the authors, hypertension patient compliance for self-management becomes an important thing.

Many studies have found approaches to overcome hypertension, both pharmacological and non-pharmacological approaches, as well as patient compliance in the management of hypertension problems. Many non-pharmacological approaches can be used as evidence-based practice, but patients are still not well utilized. Actually, these strategies can be used to control or reduce hypertension faced by patients.

\section{Policies on the management of hypertension}

Some of the regulations and policies regarding hypertension that have been announced by the Ministry of Health include:

1. Regulation of the Minister of Health of The Republic of Indonesia Number 712015 Regarding the Management of Non-Contagious Diseases [10].

2. Regulation of the Minister of Health of The Republic of Indonesia Number 52017 Concerning the National Action Plan for the Management of Non-Contagious Diseases 2015-2019 [11].

3. Regulation of the Minister of Health of The Republic of Indonesia Number 42019 Concerning Technical Standards for Fulfillment of Basic Service Quality in the Minimum Service Standards in the Field of Health [12];

4. Regulation of the Minister of Health of the Republic of Indonesia Number 432016 Regarding Minimum Service Standards in the Field of Health [13].

5. Decree of the Minister of Health of the Republic of Indonesia Number 854/Menkes/SK/IX/2009 concerning Guidelines for the Control of Cardiovascular Diseases [14].

6. JNC 8: Evidence-based Guideline: management of adult hypertension patient [15]

7. Guideline of hypertensive crises from AHA for Prevention, Detection, Evaluation, and Management of High Blood Pressure in Adults [16].

The Ministry of Health has formulated policies and strategies for preventing and managing hypertension, which include 3 main components, 1) surveillance of hypertension; 2) promotion and prevention of hypertension; and 3) management of hypertension disease services. These policies and strategies cannot be implemented based solely on the ability of the government but must involve the full potential of the community [17]. 
The existing policies and regulations have not been sufficient to support the management of hypertension management programs. Cooperation in every sector, both health workers and health cadres and the community related to the Posbindu program has not been optimally utilized. There has not been increased cooperation between health workers, health cadres, and the community. Therefore, health workers come to Posbindu and just wait for the community and this seems to be a waste of time.

The form of cooperation is still very dependent on health workers and health cadres while the patient feels bored with every Posbindu activity that feels very monotonous, even the local government does not feel the importance of the existence of Posbindu. The people prefer to do their routine activities rather than come to Posbindu which is a waste of time [18].

The further findings explained that public awareness to utilize Posbindu and conduct health checks including hypertension control was only a routine and tedious activity. People say that coming to Posbindu will only waste time. This makes health workers face obstacles to suppress health problems including hypertension effectively. Until now there is no adequate hypertension management mechanism even though there is a PIS-PK (Healthy Indonesia Program with Family Approach). In its implementation, it is limited to pursuing performance reports on paper, without seeing the real achievements of overcoming the problem of hypertension and non-contagious diseases that should be following minimal standards.

\section{Recommendation}

\section{The recommendations include}

It is necessary to develop an adequate monitoring and evaluation system as a basis for improving the overall management of hypertension and non-contagious diseases;

The government can conduct research activities to overcome the problems in the management of hypertension, especially related to patient compliance in controlling blood pressure so that it can avoid all complications and can alleviate the problem of poverty; and

The Ministry of Health should coordinate across sectors including the Ministry of Villages, PDT and Transmigration, the Ministry of Social Affairs, the Army (TNI) and the police (Polri) as well as the private sector and NGOs so that they can carry out activities simultaneously to the community. The concrete form of coordination referred to is to make a "Joint Decree" between the Ministry of Health and crosssectoral to work together to increase community involvement and empower the community's ability, especially in terms of compliance for the management of non-contagious diseases as a whole.

\section{Conclusion}

Improve the coordination system by "Joint Decree" between the Ministry of Health and the Ministry of Villages, PDT and Transmigration, the Ministry of Social Affairs, Indonesian National Army, police, and NGOs to carry out activities simultaneously to the community.

\section{Acknowledgement}

The authors would like to acknowledge to Rector of the University of Indonesia and the Dean of Nursing Faculty of the University of Indonesia.

\section{References}

1. World Health Organization. A global brief on Hypertension Silent Killer, Global Public Health Crisis. World Health Organization. 2013; 1-40.

2. Tarigan AR, Lubis Z, Syarifah S. Pengaruh Pengetahuan, Sikap Dan Dukungan Keluarga Terhadap Diet Hipertensi Di Desa Hulu Kecamatan Pancur Batu Tahun 2016. Jurnal Kesehatan. 2018; 11: 9-17.

3. Sunarya CE, Kurnia DA, Sinulingga E, Widodo GG, Jaya IA, et al. Kumpulan Policy Brief Mahasiswa S3 Keperawatan Angkatan 2019 (AYS Hamid, R Andriani, D Arruum, R Hidayat, NMS. Ayu (eds.); 2018; 52-60.

4. Riskesdas. Laporan Riskesdas 2018 Kementerian Kesehatan Republik Indonesia. In Laporan Nasional Riskesdas 2018; 53: 154-165. http:// www.yankes.kemkes.go.id/assets/downloads/PMK

5. Badan Pusat Statistik Indonesia. Proyeksi Penduduk Indonesia Indonesia Population Projection 2010-2035. In Badan Pusat Statistik Indonesia. 2013.

6. Khotimah NK. Model Peningkatan Kepatuhan Gaya Hidup sehat Pada Pasien Hipertensi Berbasis Social Cognitive Theory di Wilayah Kerja Puskesmas Kota Bima. Kesehatan Masyarakat, ilmu Perilaku Kesehatan. 2018; 1-210.

7. Berek PAL. Pengaruh Slow Deep Breathing dan Pengaturan Natrium Terhadap Penurunan Tekanan Darah Pasien Hipertensi Primer. Prosiding Sintesa LP2M Undhira Bali. 2018; 499-508.

8. Kementerian Kesehatan RI. Manajemen Program Pencegahan Dan Pengendalian Hipertensi Perhitungan Pencapaian Spm Hipertensi Prevalensi Tekanan Darah Tinggi pada Usia 18 + tahun. Disampaikan Pada Workshop Pencegahan Dan Pengendalian Hipertensi, Bali, 2018; 25-27. http://p2ptm.kemkes.go.id/uploads/ VHcrbkVobjRzUDN3UCs4eUJ0dVBndz09/2018/05/Manajemen_ Program_Hipertensi_2018_Subdit_PJPD_Ditjen_P2PTM.pdf

9. Riskesdas. Hasil Utama Riset Kesehatan Dasar 2018. Kementerian Kesehatan Republik Indonesia. 2018a; 20-21. http://www.depkes. go.id/resources/download/info-terkini/materi_rakorpop_2018/Hasil Riskesdas 2018.pdf

10. Menkes. Peraturan Menteri Kesehatan Republik Indonesia Nomor 71 Tahun 2015 Tentang Penanggulangan Penyakit Tidak Menular. 2015.

11. Kemenkes. Peraturan Menteri Kesehatan Republik Indonesia Nomor 5 Tahun 2017 Tentang Rencana Aksi Nasional Penanggulangan Penyakit Tidak Menular Tahun 2015 - 2017. 207. 2019b.

12. Kemenkes. Peraturan Menteri Kesehatan Republik Indonesia Nomor 4 Tahun 2019 Tentang Standar Teknis Pemenuhan Mutu Pelayanan Dasar Pada Standar Pelayanan Minimal Bidang Kesehatan. 2019a; $1-13$.

13. Kemenkes. Peraturan Menteri Kesehatan Republik INdonesia Nomor 43 Tahun 2016 Tentang STandar Pelayanan Minimal Bidang Kesehatan. 2016. 
14. Kemenkes. Keputusan Menteri Kesehatan RI Tentang Pedoman Pengendalian Penyakit Jantung dan Pembuluh Darah. 2009.

15. Muhadi. JNC 8: Evidence-based Guideline Penanganan Pasien Hipertensi Dewasa. Cermin Dunia Kedokteran. 2016; 43: 54-59.

16. Whelton PK, Carey RM, Aronow WS, Casey DE, Collins KJ, et al. 2017 ACC/AHA/AAPA/ABC/ACPM/AGS/APhA/ASH/ASPC/NMA/PCNA guideline for the prevention, detection, evaluation, and management of high blood pressure in adults a report of the American College of
Cardiology/American Heart Association Task Force on Clinical practice guidelines. In Hypertension. 2018; 71.

17. Hardiman A. Pedoman Teknis Penemuan dan Tatalaksana Penyakit Hipertensi. 2006; 9: 1-36.

18. Kiting RP, IImi B, Arifin S. Faktor yang Berhubungan dengan Kinerja Kader Posbindu Penyakit Tidak Menular. Jurnal Berkala Kesehatan. 2016; 1: 106-115 